\title{
The Design Path of Virtual Equity Incentive Scheme for State-owned Enterprises
}

\author{
Han Wang ${ }^{1 *}$, Qi Chen², Shuxiao Liu ${ }^{2}$ \\ ${ }^{1}$ State Grid Energy Research Institute Co.,Ltd., Beijing, 102209, China \\ ${ }^{2}$ State Grid Corporation of China, Beijing, 100031. China \\ * Corresponding author's e-mail: wanghan@sgeri.sgcc.com.cn
}

\begin{abstract}
Virtual equity incentive is one of the important ways of long-term incentives for state-owned enterprises Since the government has not yet issued a targeted policy for virtual equity incentives, it is not widely implemented in state-owned enterprises. This paper analyzes the path design of the implementation plan of virtual equity incentives and the common risks in the implementation process, and provides an effective reference and reference for state-owned enterprises to implement virtual equity incentives. And it effectively make up for the lack of implementation experience, the stateowned enterprises have no reference in the process of implementing virtual equity incentives.
\end{abstract}

Keywords: virtual equity; equity incentives; medium and long-term incentives.

\section{INTRODUCTION}

Although virtual equity incentives are similar in name to equity incentives, there are esseVirtual equity incentive is one of the important ways of long-term incentives for state-owned enterprises Since the government has not yet issued a targeted policy for virtual equity incentives, it is not widely implemented in state-owned enterprises. This paper analyzes the path design of the implementation plan of virtual equity incentives and the common risks in the implementation process, and provides an effective reference and reference for state-owned enterprises to implement virtual equity incentives. Effectively make up for the lack of implementation experience, the state-owned enterprises have no reference in the process of implementing virtual equity incentives.ntial differences between the two. Virtual equity is similar in operation mode to equity incentives, and both use the share of equity as the basis for distribution. But virtual equity is essentially a cash-based incentive method. Incentives only enjoy dividend rights, not shareholder rights.[1]

Virtual equity incentives mainly have the following two characteristics. On the one hand, the virtualization of equity. Virtual equity is different from corporate equity in the general sense. In order to well motivate core employees, the company distributes a certain number of virtual shares to the company's core employees free of charge, and its holders can enjoy the company's after-tax profit distribution in proportion to the number of virtual equity. On the other hand, the incompleteness of shareholder equity. Holders of virtual equity can only enjoy the right to dividend income, that is, according to the number of virtual equity held, the right to distribute the company' s after-tax profits in proportion, but not the rights of ordinary shareholders (such as voting rights, distribution rights, etc.). So holders of virtual equity will pay more attention to the status of business operations and corporate profits.

Although there are differences in essence between virtual equity incentives and equity incentives, the specific implementation process is still relatively similar.

\section{OPERATIONAL STEPS OF VIRTUAL EQUITY INCENTIVE IN STATE-OWNED ENTERPRISES}

The definition of the scope of state-owned science and technology enterprises generally refers to the definition of state-owned science and technology enterprises in the "Interim Measures for Incentives and Dividends of State-owned Science and Technology Enterprises". That is, "state-owned and state-controlled non-listed technology enterprises (including state-owned enterprises listed in the national SME share transfer system) with corporate legal person status in China" . 


\subsection{Determine the Incentive Object}

Related policies do not strictly limit the incentive objects of virtual equity. Therefore, in the selection of objects, the company can refer to the selection of equity incentive objects, with company directors, senior managers, core technical personnel and management backbones as the mainstay. We can comprehensively use job value evaluation and job competency evaluation to select personnel who have a key role in the development of the enterprise as the incentive objects. In the selection of positions, the value of each position is generally determined through the evaluation of the position value, and the positions that have a higher contribution to the development of the company are designated according to the needs of the company.

\subsection{Determine the Application Form}

Virtual equity incentives generally include three forms: virtual stocks, virtual stock appreciation rights and virtual stock options.

Among them, virtual stocks and virtual stock appreciation rights are widely used in enterprises. There are also companies that combine the two so that incentive objects can enjoy both the dividend right of virtual stocks and the right to increase in value.[5] However, virtual stock options are not real shares that the incentive object can buy in the future, especially for non-listed companies, it is difficult for the incentive object to predict the future value of virtual stocks, so the incentive effect is not ideal.

\subsection{Determine the Total Amount of Virtual Equity}

The total number of virtual equity of a company is generally linked to the company's registered capital or the company's net assets. And for the convenience of calculation, the stock price per share is usually 1 yuan. That is, if the company's registered capital is 1 million yuan, the total amount of virtual equity is 1 million shares. In order to make the number of grants appear more scaled and the incentives more impactful, the registered capital can also be expanded exponentially to determine the number of virtual equity.

\subsection{Determine the Number of Virtual Equity Granted}

The relevant policies do not limit the number of virtual equity grants. And because virtual equity does not involve changes in the company' s equity, as long as the company has sufficient strength, the proportion of virtual equity used for incentives can be appropriately set higher to make the incentive effect better. The specific incentive amount can be reversed based on the company's operating income, profits, and equity dividends.
The amount of incentives obtained by each incentive object can be comprehensively determined based on post value evaluation and post competency evaluation.

\subsection{Determine Virtual Equity Grant Method}

Relevant policies do not strictly stipulate the method of granting virtual equity. Companies can either use equity rewards to give virtual equity to incentive objects free of charge, or they can use equity sales to have employees pay a certain amount of cash for purchase.

\subsection{Determine Incentive Amount}

There are two ways to calculate the amount of virtual equity incentives. The first is similar to dividend rights, and the income comes from the business income of the enterprise. That is, the incentive amount is linked to the company's earnings or stock price appreciation. The second type is derived from the rights and interests of shareholders' after-tax profit distribution, and the shareholders voluntarily transfer part of the income rights as the income of virtual equity. That is, the amount of incentives is linked to the after-tax profits received by shareholders.

The enterprise can determine the calculation method and the accrual ratio according to its actual situation, and determine the incentive amount of the virtual equity based on this.

\subsection{Determine Grant/Exercise Conditions}

The grant/exercise conditions of virtual equity incentives should be linked to the achievement of the company's goals and the achievement of the incentive targets. Only when the performance of the company and the incentive objects meet the requirements, the incentive objects can exercise their rights. The specific index requirements can be set with reference to the relevant standards of equity incentives.

The conditions for granting/exercising rights are generally linked to the achievement of the company's goals and the achievement of the incentive targets. Only when the performance of the company and the incentive objects meet the requirements, the incentive objects can exercise their rights. Companies can use profit growth rates, asset yields, and main business income growth rates as company performance indicators based on actual business development. Listed companies can also choose the company's market value, earnings per share, dividends per share, etc. Individual performance indicators are determined according to the company' $\mathrm{s}$ strategic goals, overall performance indicators, and job functions.[2]

In addition, companies must also formulate methods for dealing with equity when they cannot exercise their rights. When the performance of either or both of the 
company or the incentive object fails to meet the exercise conditions, the equity incentive subject of the current period shall not be exercised.

\subsection{Determine the Exit Mechanism}

The withdrawal of virtual equity is generally divided into the following two situations:

One is that virtual equity is given to the company free of charge. Since there is no monetary relationship between the incentive object and the company, the incentive object can return the virtual equity to the company or transfer it in accordance with the regulations. Of course, the company can also agree on relevant default clauses with the incentive objects when granting virtual equity to restrict the incentive objects from leaving their jobs early or deliberately doing behaviors that harm the interests of the company.

The second type of virtual equity is purchased by employees themselves. The company should agree with the incentive object in advance the relevant conditions for the repurchase or transfer of shares. For example, whether virtual equity is repurchased at the original price, and whether other purchasers buy it at the original price.

\section{COMMON RISKS OF VIRTUAL EQUITY INCENTIVES IN STATE-OWNED ENTERPRISES}

\subsection{Risk of Illegal Fundraising}

When designing virtual equity incentive plans, many companies use Huawei' s virtual equity incentive operation method for reference, requiring employees to invest in virtual equity in advance. Commonly this part of the funds has to be independently accounted for by the company opening a separate account. However, because the relevant policies do not regulate the virtual equity incentives, this part of the incoming funds is difficult to handle financially. In addition, if employees purchase virtual equity without obtaining real shares, there may also be a risk of illegal fund-raising.[3]

Therefore, in terms of the method of granting virtual equity, it is recommended that the method of granting free of charge should be adopted as far as possible to avoid the above risks.

\subsection{Salary Limit}

The current policy requirements do not specify the source of bonuses for virtual equity incentives. Only in the "Special Action Plan for Deepening Market Reform of Hundreds of Science and Technology Enterprises to Improve Independent Innovation Capability", it is proposed that the total wages of technology enterprises can be managed separately, and it is not included in the group company's total salary budget base and not linked to the group company's economic efficiency indicators. That is to say, only one hundred technology-based companies can break through the original total salary limit when launching virtual equity incentives.

Although the "Notice of the Office of the Stateowned Enterprise Reform Leading Group of the State Council on Supporting and Encouraging 'Double Hundred Enterprises' to Further Strengthen Reform and Innovation Relevant Matters", it is stated that "the actual income level of various forms of equity incentives is not linked to the overall level of employees, Not included in the company' s total wage base." However, whether it is from the academic concept or from the perspective of various policies, virtual equity does not belong to the scope of equity incentives, so it cannot be applied to this standard. That is, with the exception of a hundred technology-based companies, other companies cannot separately list their total wages when implementing virtual equity incentives.

In this way, non-hundred technology companies can only set aside a part of the existing salary range as a bonus pool for incentives. Then there will be two consequences:

One is to reduce the total compensation of nonincentivized objects and use it as a virtual equity incentive bonus for incentive objects. As a result, the salary level of non-incentivized objects will drop, and the salary level of incentive objects will rise, and the pay gap between the two parties will continue to widen, which may cause dissatisfaction with non-incentivized objects.[4]

The second is to divide a part of the original total salary of the incentive object as a bonus for virtual equity incentives. This is equivalent to changing the salary structure of the incentive objects, which increases the risk and cost of the incentive objects to obtain performance compensation in a disguised form. Therefore, for the incentive object, this has become a kind of quality assurance incentive. The risk that you bear is actually greater than the incentive, and the incentive effect is not good.

\subsection{Lack of Shareholder Identity}

While virtual equity has successfully avoided the risk of employees directly participating in business management as shareholders, it also makes employees lose their sense of participation in the company as shareholders. The characteristic of equity incentives is to give employees the status of "protagonist" . Although virtual equity maintains the same income and dividend rights as equity incentives, the incentive objects do not actually own equity. It is essentially a dividend-based cash incentive method, and there may be a certain gap 
between the incentive effect and the real equity incentive.[5]

\section{CONCLUSION}

The operation steps of the virtual equity plan include the 8 steps of "determining the object, determining the form, determining the total amount, determining the quantity, determining the grant, determining the amount, determining the conditions, and determining the exit" . In the implementation process, attention should be paid to issues such as the risks of illegal fund-raising, total wage restrictions and lack of shareholder identity.

As a common medium and long-term incentive method, virtual equity incentives are not widely implemented in state-owned enterprises. On the one hand, because the relevant policies have not yet strictly regulated and required virtual equity incentives, only some of the policies have set encouraging clauses. Therefore, many companies do not know how to implement virtual equity incentives in the absence of policy support and regulation. On the other hand, compared with other medium and long-term incentive methods, the weakness of virtual equity incentive is more obvious. From the perspective of the difficulty of implementation, the implementation of virtual equity incentives is similar to equity incentives, the process is more complicated and there are many factors to consider.[16] From the perspective of implementation effects, the overall effect of virtual equity incentives is far less than equity incentives, but similar to the implementation of relatively simple and convenient dividend incentives. Therefore, many companies use virtual equity as an effective supplement to equity incentives in their implementation, instead of implementing it separately.

\section{ACKNOWLEDGMENT}

This project is supported by the State Grid Corporation of China Technology Project "Research on Talent Supply and Demand Analysis Model and Supply Strategy Research Adapting to Company Strategy" (SGSC0000KXJS2000095).

\section{REFERENCES}

[1] Qin, W., Xu Q., On the Design of Medium and Long-term Incentive Plans for State-owned Enterprises., in: Market Modernization, vol.2, Beijing, China, 2020, pp. 72-74, DOI: 10.14013/j.cnki.scxdh.2020.02.032

[2] Li, Y., Research on Establishing Mid- and Longterm Incentive Mechanism for State-owned Enterprises, in: Modern Commerce, vol.22, Beijing, China, 2017, pp. 129-130, DOI: 10.14097/j.cnki.5392/2017.22.048
[3] Qu, T., A Probe into the Mid- and Long-term Incentives of Professional Managers' Innovation and Development, in: China Training, vol. 5, Beijing, China, 2019, pp. 36-37, DOI: 10.14149/j.cnki.ct.2019.05.019

[4] Qu, T., A Probe into the Mid- and Long-term Incentives of Professional Managers' Innovation and Development, in: China Training, vol. 5, Beijing, China, 2019, pp. 36-37, DOI: 10.14149/j.cnki.ct.2019.05.019

[5] Wang, B., Research on Motivation Ways of Personnel in Modern State-owned Sci-tech Enterprises, in: Market Modernization, Beijing, China, 2018, pp.

[6] Wang, D., Research on Mid- and Long-term Incentives of State-owned Enterprises, in: Military and Civilian Technology and Products, vol. 21, Beijing, China, 2015, pp. 57-62+65, DOI: 10.19385/j.cnki.1009-8119.2015.21.016 